\title{
Teaching Concepts of Natural Sciences to Foreigners through Content-Based Instruction: The Adjunct Model
}

\author{
Yılmaz Satılmış ${ }^{1}$, Doganay Yakup ${ }^{1}$, Guvercin Selim² \& Islam Aybarsha ${ }^{3}$ \\ ${ }^{1}$ Faculty of Philology \& Educational Sciences, Suleyman Demirel University, Almaty, Kazakhstan \\ ${ }^{2}$ Faculty of Engineering \& Natural Sciences, Suleyman Demirel University, Almaty, Kazakhstan \\ ${ }^{3}$ Faculty of Philology, Abylaikhan University, Almaty, Kazakhstan \\ Correcpondence: Yakup Doganay, Faculty of Philology \& Educational Sciences, Suleyman Demirel University, \\ 040900, 1/1, st. Abylaikhan, Kaskelen, Almaty, Kazakhstan. Tel: 772-7307-9565. E-mail: \\ y.doganay@sdu.edu.kz
}

Received: October 31, 2014 Accepted: January 4, 2015 Online Published: February 13, 2015

doi:10.5539/elt.v8n3p97 URL: http://dx.doi.org/10.5539/elt.v8n3p97

\begin{abstract}
This study investigates three models of content-based instruction in teaching concepts and terms of natural sciences in order to increase the efficiency of teaching these kinds of concepts in realization and to prove that the content-based instruction is a teaching strategy that helps students understand concepts of natural sciences. Content-based education is considered effective not only in acquiring the skills of language, but also grasping and mastering the content knowledge of academic subjects that are required for students' achievements in learning the terms related to natural sciences. In analysis of three models of content-based instruction, the Adjunct Model was explained and mentioned to be quite reliable for the teaching content of any subject along with foreign language methods and techniques. It has been proved to be convenient for both content and language teaching through pedagogical experiment. Participants were undergraduate students from the Engineering and Natural Sciences Faculty of a university at intermediate level. The achievement test was applied to 48 students who were English and Turkish speaking students as foreign languages. Two working groups as experimental and control were formed by language teachers. The collected data was analyzed. The results, mentioned in experiment part, and conclusion show that concepts or terms of natural sciences could be taught efficiently through content-based teaching in schools and universities.
\end{abstract}

Keywords: content based instruction, second foreign language teaching, teaching concepts of natural sciences and adjunct model

\section{Introduction}

Chamot and O’Malley (1986) stated that limited-English-proficient (LEP) students who prepare to participate in mainstream content instruction face language-related difficulties in vocabulary, discourse, structures and language skills in science classes. In chemistry, physics and life sciences, concepts related subjects; energy, periodicity, space, atom and so on, are not understood and perceived by the students easily for including more abstract concepts. Herron (1996) supported this idea saying that many of the most useful scientific concepts are not perceptible having interactions with the environment because of the absence of mediating experience. He gives atoms and molecules as an example of these types of concepts. In addition, words of Greek and Latin derivations are used for scientific terms, and students may have difficulty in cognition of the meanings of the scientific terms (Chamot \& O'Malley, 1986). Therefore teaching special terms of each discipline is considered to be difficult by language teachers because of the difficulty of learning abstract concepts and changing prior knowledge and also beliefs of students. The next problem is learning meanings of scientific terms along with learning foreign language. Scientific sentences or concepts differ from the structure of daily language for having specific and deeper meaning. We think it is of crucial importance to overcome all these problems to provide more satisfactory results in education. It is mentioned by most of the scholars in this area that content-based instruction (CBI) supports to realize both content and language objectives and reach its goals. Many researchers have investigated about effectiveness of content-based instruction: e.g., (Brinton \& Snow, 1988; Brinton \& friends, 1989; Met, 1999; Leaver \& Stryker, 1989; Dupuy, 2000), lack of collaboration between content and language teachers (Tan, 2011), the need for a more explicitly reflexive model of the relationship between content, 
language and learning (Barwell, 2006) and promoting content and language learning (Stoller, 2002). Stoller (2002) also showed that CBI has a great potential to promote content and language learning. It should be convenient for both content and language teaching. Larsen-Freeman (2000) predicted that content-based teaching, rather than teaching the language curriculum, revolves around content or knowledge. Some researchers mentioned the importance of learning language and content interaction. Leung (2005) commented that it is important to relate the general idea of language learning to more specific demands, opportunities and affordances of content-related language learning. He commented bilingual education in which students expect to develop their knowledge and language skills in two or more languages through the study of curriculum subjects, not just language.

We believe that learning special concepts or scientific terms will be the beginning of using content-based instruction. The use of content-based instruction in teaching the terms of natural sciences helps students studying in different fields of natural sciences; develop understanding and thinking the meanings of scientific terms and concepts. Herron (1996) expresses the concept as the name given to a class of entities. Hunt (1962) explains concept as a thought, an opinion and a mental image of a thing formed by a generalization from particulars in philosophy.

As far as we know content based instruction (CBI) is a new approach that allows scientific texts studies including academic reading, writing, comprehension activities and exercises. We know that scientific and concepts terms are words or phrases, especially one from a specialized area of knowledge for the events and objects and they carry wide, specific and deep meaning (http://www.seslisozluk.net/?word=term\&lang=tr-en). We think teaching only the names of the objects or the concepts, through providing basic information, is not enough for the meaningful learning and cognition. This way is often referred to as a traditional approach and method of teaching scientific terms and concepts in which lack of learning in teaching process occurs. Creese (2005) pointed out this problem for second language learners and that the approach of content based language teaching (CBLT) about importance of CBI. She persisted that 'in the CBLT literature, the argument is that a language can best be learned through subject content, while the second language acquisition (SLA) literature carries a warning that communicative classrooms, such as content-focused classrooms, allow few opportunities for a focus on form'. Resorting to alternative strategies to teach the concepts of natural sciences will enrich teaching methods of concepts of natural sciences. Therefore, content-based language teaching is an important and new field that is providing a precise balance between teaching scientific content of knowledge and language education. Reading and writing activities for the language learners, at intermediate or advanced level, cause better academic skills and success in scientific fields. They also improve learners' reading and comprehension skills.

First, we would like to investigate the three models of Content based Instruction (CBI) in accordance with language level and learning content knowledge. Second step is dedicated to show the efficiency of adjunct model in teaching natural sciences concepts and terms experimentally.

\subsection{Content-Based Instruction}

Content-based teaching is a teaching method which emphasizes learning language and content together (Richards \& Rodgers, 2001). According to this method subject and language are to be taught at the same time and subject is implemented as a tool to teach a language. This teaching method, especially in the last decade has also attracted an increasing interest. Although CBI is not new, there has been an increased interest in it over the last ten years, particularly in the USA and Canada where it has proven very effective in ESL immersion programs. This interest has now spread to EFL classrooms around the world where teachers are discovering that their students like CBI and are excited to learn English this way (Davies, 2003).

Content-based approach is a way to return the language learning needs and knowledge acquisitions of students (Richards \& Rodgers, 2001). This provides students' professional skills of their fields. This approach is to teach academic subjects and second language skills simultaneously. It has two purposes: first is learning target language and second learning the academic content. Thus, the aim is to develop comprehension skills, academic competence, and the language skills of learners. Especially the studies that speaking, reading, writing and making comments on academic texts help develop language skills and provide new words, terms, and some language patterns. Thus, learners have an opportunity to improve both subject knowledge and their language skills.

There are three content-based language education models: theme-based, adjunct and sheltered. The aim of the models is to use and teach course materials regularly used in foreign language instruction for learners. 


\subsubsection{Theme-Based Model}

The theme-based model is usually very widely used in foreign language teaching. In this model, scientific subjects in other disciplines are taught in foreign language, teachers or teams are trained by content expert foreign language teachers. The theme-based course is formed by selecting interesting topics. Topics should attract the students' attention and allow the implementation of various language skills and also provide the cases to talk about the chosen subjects. So, these topics can be quite common and universal for almost everybody like urban violence, marriage, cross-cultural contrasts and broader issues such as the world's natural wonders (ibid., p. 186). Therefore, language pre-dominates the content and there is no need for a teacher accompany. Because this model is student centered rather than teacher centered. But even if the students had greater influence, "the teacher's role is not diminished, but changed" (Mumford, 2000). The role of teacher is facilitator in learning process and integration of topics, with scientific terms and concepts. The results of the studies and researches e.g., Kıziltan and Ersanl (2007) in this area have revealed that students through a theme-based CBI model, the aim is to develop students' target language skills irrespective to some institutional settings and language proficiency level of the students.

This model may be considered as preparatory education for sheltered and adjunct model. It can be considered as an important step to reach up to the beginner level at a foreign language. Among the models of content-based instruction (CBI), only theme-based model (TBM) is used, since sheltered and adjunct models require a partnership of the language teacher with a content-area specialist (Kizlltan \& Ersanl1, 2007).

\subsubsection{Sheltered Model}

In sheltered model, a sheltered content-based course is taught in a second language by a content specialist to a group of learners who have been segregated or sheltered from native-language speakers (Brinton, Snow, and Wesche, 1989). In this model second language is simplified in accordance with the competency level of students. Sheltered model is known as a means that helps learners understand the lessons given with a special support, provided regularly. In this approach two teachers work; one of them is content/subject expert and the other one is a specialist in a second language teaching (Brinton, Snow, and Wesche, 1989). As it is understood from the given explanation the teachers can teach the courses in the same classroom or the courses can be given to two groups separately. For example, the content expert gives a short lecture and then a foreign language teacher checks students' understanding by studying and examining important words. This is a teamwork and kind of subgroup teaching. The teamwork refers that the teachers should design and develop a plan and evaluation in teaching course.

\subsubsection{Adjunct Model}

Some linguists such as Brinton and Snow (1988), Richards and Rodgers (2001), Davies (2003), and Met (1999) explain adjunct model as two coordinated courses: a content/subject course and a language course. In this model language and subject/content are taught separately, but coordinated care is provided. This model is applied and tested in practice in many universities to Second Foreign Language (SFL) students (Snow \& Brinton, 1988). To increase the academic success of SFL students at the university, it is aimed to establish the coordination between language and academic courses. It requires a special effort to ensure compliance with equal measure of responsibility. Both programs are of particular importance and both are stressed separately by the teacher. In this model, the content/subject is the same as the instruction, but it is different from the focal point. Content/subject teacher focuses on the traditional academic topics and concepts; the language teacher emphasizes language skills such as academic reading and writing (Brinton \& Snow, 1988). In these courses, some activities are of crucial importance to provide the ability to work with the students in collaboration. Another benefit of the courses is that it helps provide convenience to the understanding of the topics and issues in addition to developing academic writing skills and learning academic concepts and terms (Brinton \& Snow, 1988). Some adjunct courses can begin in summer before regular university courses take place to reach the same level at normal lessons. So, we think this should be coordinated with a good adjunct lesson. In this model, the language teacher usually gives extra effort to be familiar with content/subject because students may not have sufficient language skills.

\section{Methodology}

\subsection{Respondents}

Participants were undergraduate students from Engineering and Natural Sciences Faculty in our university. Students were Kazakhs, speaking Kazakh language as their native tongue, Turkish as a second language because both Kazakh and Turkish languages are in Turkic languages and quite similar to each other. The participant students were at intermediate level both in English and Turkish languages. Two working groups; as experimental 
and control were formed by Turkish teachers. Each group consisted of 24 students and totally 48 that we think the number of the students was sufficient to get the reliable and valid results from experiment.

\subsection{Material}

The achievement test that we had prepared for the teachers to check out the progress of the students that they got during the experiment consisted of 25 questions including natural science terms. This test has been developed via the pilot application of 109 second-class students who participated in language courses. Terms were: some important words for academic success of engineering students. Some of them were about energy, heat, atom, mass, weight and the others were in Turkish. Test difficulty was determined as 0.496 . The average difficulty of the test varies between 0 and +1 . If the difficulty of the test is less than 0.50 , the test has insufficient power for students so we can say that the achievement test that we applied could be admitted to be valid and reliable test.

\subsection{Procedure}

The 'Introduction to Science' is used as a source book and instructional material. Terms have been taught to experimental and control groups for 4 weeks. Before the lessons took place, the pre test had been applied for the students in both groups. After the pre test had been conducted, language course started. The terms were described with traditional teaching methods and techniques by the language teacher in the control group. For the experimental group, the definitions of the terms specified in the source book were taught with adjunct model by the content/subject teachers. At the end of the lessons, the achievement test was applied again. The data were collected as a result of the achievement test consisting of two main parts; term knowledge and language skills.

\section{Results (Findings)}

\subsection{Pre-Experiment Survey}

The obtained data was transferred to the computer using SPSS 16.0 (The Statistical Packet for the Social Sciences). This program is used for the statistical analysis of the data. Both control and experimental group students' scores were evaluated and the average and also the standard deviation are shown in the Table 1. In both groups the standard deviation values show that groups are homogeneous. In accordance with the means of achievement on the table 1 both experimental and control groups have the rather close achievement to each other.

Table 1. Pre test results of teaching with traditional language teaching methods

\begin{tabular}{lllll}
\hline & Mean & $\mathrm{N}$ & Standard deviation & Standard deviation error \\
\hline Experimental Group & 12.5 & 24 & 1.36878 & 0.54907 \\
\hline Control Group & 12.4 & 24 & 1.64655 & 0.52068 \\
\hline
\end{tabular}

\subsection{Post-Experiment Survey}

Table 2 shows the post-test evaluation of the results of both the experimental and the control groups. The results, obtained from this table are as follows: in table2, (N) indicates the number of the students who participated in the last exam in both groups is 24. Average grades of the experimental and control groups are 15.7524 and 14.8224 respectively. Column six is determined as the correlation $r=0.451$. The last column gives the $p$-value. P-value indicates the correlation of co-efficiency. The $\mathrm{p}$-value is less than or equal to alpha $(p=0.05)$ in this case, the hypothesis is rejected. This value $p=0.015$ which is the alpha value less than 0.05 that means there is a significant difference between the experimental and control groups. These results support our research. The analysis of test results show that the application of the adjunct model of content-based teaching in enhancing the success of teaching natural science terms is seen to be more effective than traditional teaching methods.

Table 2. Post test results of teaching with adjunct model

\begin{tabular}{lllllll}
\hline & $\mathrm{N}$ & Mean & $\mathrm{SD}$ & Std. error mean & Correlation & Sig. \\
\hline Experimental Group & 24 & 15.7524 & 1.8458 & .2916 & .451 & .015 \\
\hline Control Group & 24 & 14.8224 & 1.4413 & .2865 & & \\
\hline 0.05. & & & & & &
\end{tabular}




\section{Discussion}

Much has been said about content-language integration by numerous scientists preferring the three models of CBI in accordance with the language level of students and learning content/subject knowledge. Met (1999) reported that theme based model was language driven, so it was inappropriate to teach natural content/subject. Davies (2003) stated that teacher(s) could create a course of study, design to unlock and build on according to their own students' interests and the content can be chosen from an enormous number of diverse topics. So, in the theme-based model, topics should be interesting and social but not scientific, so this model is usually not suitable to teach scientific concepts. The sheltered and adjunct models of content-based instruction are available and suitable to teach concepts of natural sciences. The comparing method, in language and content teaching approach, can be designed for a better understanding of the models in content-based instruction. Dale and Tanner (2012) indicated the differences between Content-Based Instruction method (CBI) and Content and Language Integrated Learning (CLIL). They explained that CBI deals with teaching content in language lessons whereas CLIL deals with teaching a subject during teaching language. CLIL lesson is divided into two lessons; CLIL language lesson and CLIL subject lesson. But in CBI language teaching, teachers teach second language through content/subject. Some researchers Met (1999), Brinton, Snow, and Wesche (1989), Stoller (2002) have explained three models of CBI in how they are driven to content/subject or language teaching.

Met (1999) reported that content and language integration agreement continuum and the sheltered model was more content driven than the others. Met (1999) also stated that sheltered courses were subject courses and content-driven: the goal for students was to master content; students were evaluated in terms of content learning and language learning took second place. Depending on the statements mentioned above by (Met, 1999), we think that the sheltered model should be implemented and can be suitable to improve the content knowledge and the language skills for the learners' academic achievement. Met (1999) described that Adjunct courses lie at the center of the continuum of content/language integration and both language and content are the goal to master. The results that we obtained from the experiment also reinforce his ideas and statements that especially the adjunct model in which the content and the language are both goals to be developed could be profitable to teach concepts about natural science and sheltered model as well. It can be efficient to increase academic success of students. But, the adjunct model is different from the sheltered in accordance with language level of SFL students and content knowledge. Because the sheltered model lesson is paired at same time of the course, the content course may not be effective because of time shortage and some coordination problems between language and content courses. The adjunct model can be provided by using language as a tool for the academic achievements of students in the academic study. Students are expected to learn content material while acquiring academic language proficiency. Dupuy (2000) says that students are enrolled concurrently in content and language courses that are paired in adjunct courses. He proposes that adjunct language course is organized around the content and language as well as the academic necessities and requirements of foreign language students in the discipline course. When the results are analyzed, the better progress and achievement of experimental group (see table 1 and 2) in which the adjunct and sheltered models have been applied, could be noticed easily in comparison with control group and they show that learning content knowledge is very important part of content-based instruction because it generally includes the concepts of any specific area that are taught and learned. Students' knowledge of the subject is increased and language skills; speaking, reading, listening, writing are improved together while language is taught. This research experimentally shows the possibility of teaching concepts of natural sciences for SFL students.

Students' language level and their needs play a great role in language teaching. We think teachers can make choice about teaching type, model and methods according to students' level and branches or the programs that they study. It can be said that the models of content-based instruction could be applied for all levels, needs and disciplines. Brinton, Snow, and Wesche (1989) explain the sheltered model as subject to the level of students' competence in accordance with a simplified second language that is taught to groups consisting of nonnative students. First, learning any subject meaningfully is important in this model and then comes language skills, this is why this model is called: 'sheltered'. Learners regularly understand along with special support of assistants. Assistants help students improve language skills more than academic success. The adjunct model is suitable for students at all language levels. Two courses were organized separately and teaching process was carried out. In case the two courses were compatible and coordinated, the student language group was set in accordance with the students' language level. We think that the more primitive natural concepts should be explained to SFL students with low level language skills and it is necessary to supplement the language. This can be overcome with the implementation of sheltered model. We think that natural scientific concepts can be taught to develop the level of academic language and academic achievement of the students who are at sufficient language level. 
This could be possible with the adjunct model to raise the level of academic language. Teaching and learning the terms of natural sciences require a certain level of language. In the adjunct model this fact is important both for language and content. Brinton and Snow (1988) say that content teacher focuses on the traditional academic topics and concepts; the language teacher emphasizes language skills so both teachers teach independently but in coordination. As we have tried during our experiment and got the progress and the results of experimental group it could be said that when the language and content of any discipline are taught separately but in coordination at the same time the teaching and learning process will be supported and the academic success will be ensured. Moreover, the language learning should be supported during the teaching of academic terms by content teachers. A benefit of additional course is about academic writing. Writing skills, by developing academic concepts and terms, would be provided convenience to understanding the contents. It has been experimentally proved that the implementation of the adjunct model, in teaching process, has increased the level of students both in language and content knowledge.

\section{Conclusion}

The basis of the content-based instruction could be conducted both with foreign language teaching and teaching of scientific discipline. Thus, as a kind of Turkish language, other languages' education is combined with the teaching of science in interdisciplinary study that was carried out. We assume that the adjunct model of CBI is rather new and could be applied as an alternative method for teaching scientific content in second language. As a result, the experience of teaching English and scientific terminology can be used on the basis of the principles of the teaching scientific terms in other languages to foreigners. So, this approach can be suggested as an alternative way to teaching concepts in all foreign languages. Language teachers should work in coordination with other departments and disciplines in institutions. Materials, including integrated language skills and content knowledge with disciplines of natural sciences, should be increased.

\section{References}

Barwell, R. (2005). Integrating language and content: Issues from the mathematics classroom. Linguistics and Education, 16(2), 205-218. http://dx.doi.org/10.1016/j.linged.2006.01.002

Brinton, D. M., \& Snow, A. M. (1988). Content-Based Language Instruction: Investigating the Effectiveness of the Adjunct Model. TESOL Quarterly, 22(4), 553-574. http://dx.doi.org/10.2307/3587256

Brinton, D. M., \& Snow, A. (1988). The Adjunct Model of Language Instruction: Integrated Language and Content at the University. Los Angeles, MA: Report of Center of Language Education and Research.

Brinton, D. M., Snow, M. A., \& Wesche, M. (1989). Content-based second language instruction. New York, MA: Newbury House.

Cameron, L. (2001). Teaching Languages to Young Learners. Cambridge, MA: Cambridge University Press (CUP).

Chamot, A. U., \& O’Malley, J. M. (1986). A Cognitive Academic Learning Approach: An ESL Content-Based Curriculum. Report Paper. Washington, MA: National Clearinghouse for Bilingual Education.

Collette, A. T., \& Eugene, L. C. (1989). Science Instruction in the Middle and Secondary Schools. The USA, MA: Merrill Publishing Company.

Creese, A. (2005). Is this content-based language teaching? Linguistics and Education. Linguistics and Education, 16(2), 188-204. http://dx.doi.org/10.1016/j.linged.2006.01.007

Dale, L., \& Tanner, R. (2012). CLIL Activities. A resource for subject and language teachers. Cambridge, MA: Cambridge University Press.

Davies, S. (2003, February). Content Based Instruction in EFL Contexts. The Internet TESL Journal, 9(2). Retrieved from http://iteslj.org/

Dupuy, B. C. (2000, March). Content Based Instruction: Can it help ease the transition from beginning to advanced foreign language classes? Foreign Language Annals, 33(2), 205-223. http://dx.doi.org/10.1111/j.1944-9720.2000.tb00913.x

Herron, J. D. (1996). The Chemistry Classroom. Formulas for Successful Teaching. Washington, DC, MA: American Chemical Society.

Hunt, E. B. (1962). Concept Learning: An Information Processing Problem. New York, MA: Wiley Publishing.

Kizıltan, N., \& Ersanl1, C. Y. (2007). The Contributions of Theme-Based CBI to Turkish Young Learners' Language Development in English. Journal of Language and Linguistic Studies, 3(1), 133-148. 
Larsen-Freeman, D. (2000). Techniques and Principles in Language Teaching. Oxford, MA: Oxford University Press.

Leaver, B. L., \& Stryker, S. B. (1989). Content-based instruction for foreign language classrooms. Foreign Language Annals, 22(3), 269-275. http://dx.doi.org/10.1111/j.1944-9720.1989.tb02746.x

Leung, C. (2005, Summer). Language and content in bilingual education. Linguistics and Education, 16(2), 238-252. http://dx.doi.org/10.1016/j.linged.2006.01.004

Met, M. (1999). Report: Content-Based Instruction: Defining Terms, Making Decisions. Washington, DC, MA: The National Foreign Language Center.

Mumford, D. (2000, July). Planning a theme based unit. Retrieved from $\mathrm{http}: / /$ www.pacificedgepublishing.com/pdf/PlanThem.pdf

Richards, J. C., \& Rodgers, T. S. (2001). Approaches and Methods in Language Teaching. Cambridge, MA: Cambridge University Press.

Snow, M. A., \& Brinton, D. M. (1988, December). Content-Based Language Instruction: Investigating the Effectiveness of the Adjunct Model. TESOL Quarterly International Association, 22(4), 553-574. http://dx.doi.org/10.2307/3587256

Stoller, F. L. (2002, April). Content-Based Instruction: A Shell for Language Teaching or a Framework for Strategic Language and Content Learning? TESOL. Salt Lake City, Utah. Retrieved from http://carla.acad.umn.edu/cobaltt/modules/strategies/stoller.pdf

Tan, M. (2011, July). Mathematics and science teachers' beliefs and practices regarding the teaching of language in content learning. Language Teaching Research, 15(3), 325-342. http://dx.doi.org/10.1177/1362168811 401153

\section{Copyrights}

Copyright for this article is retained by the author(s), with first publication rights granted to the journal.

This is an open-access article distributed under the terms and conditions of the Creative Commons Attribution license (http://creativecommons.org/licenses/by/3.0/). 